\title{
RUMAH DERET DAN KRITERIA BERKELANJUTAN DI KOTA SURAKARTA
}

\author{
Ridho Wicaksono', Ana Hardiana', Hakimatul Mukaromah'1 \\ 1Program Studi Perencanaan Wilayah dan Kota, Fakultas Teknik, Universitas Sebelas Maret
}

\begin{abstract}
Abstrak
Di Kota Surakarta, rumah deret merupakan salah satu solusi untuk penataan bantaran Kali Pepe dan penyediaan hunian. Setiap tahun selama kurun waktu 2015 - 2018 dibangun rumah deret di beberapa titik bantaran Kali Pepe Kota Surakarta. Pembangunan tersebut dinilai memiliki potensi untuk mewujudkan hunian bagi masyarakat di permukiman kumuh, bahkan diperkirakan memiliki potensi lebih besar dibandingkan dengan rumah susun. Rumah deret dibangun dengan memperhatikan aspek fisik, sosial, ekonomi. Penelitian ini bertujuan untuk mengidentifikasi permasalahan rumah deret di Kota Surakarta terhadap kriteria keberlanjutan. Penelitian ini merupakan penelitian kuantitatif, dengan teknik analisis skoring. Hasil penelitian menunjukkan bahwa dari delapan variabel, rumah deret telah sesuai dengan tujuh kriteria berkelanjutan. Tujuh variabel tersebut, yaitu: 1) pemberdayaan fisik lingkungan yang bermanfaat bagi sekitar; 2) penyediaan sarana prasarana dasar perumahan \& permukiman; 3) pemberdayaan ekonomi masyarakat; 4) daya dukung institusi/lembaga ekonomi, sosial, budaya; 5) pembangunan sumber daya manusia; 6) pembangunan tidak merusak integritas sosial masyarakat; 7) mempertahankan keanekaragaman budaya. Pengecualian adalah pada variabel dampak terhadap lingkungan yang menunjukkan bahwa rumah deret kurang sesuai dengan kriteria berkelanjutan dari aspek ini. Secara keseluruhan, penilaian skoring menunjukkan kesesuaian antara pembangunan rumah susun dan prinsip-prinsip keberlanjutan.
\end{abstract}

Kata kunci: kesesuaian; kriteria keberlanjutan; rumah deret

\begin{abstract}
In the city of Surakarta, a row house is one of the solutions for arranging the Kali Pepe riverbanks \& providing housing. Every year, in 2015 - 2018 a series of houses are built in several Pepe River banks. The development is considered to have the potential to create shelter for people in slums, even more potential compared to flats. Built by paying attention to physical, social, economic aspects. The purpose of this study was to determine the suitability of row houses in the city of Surakarta to the criteria for sustainability. The targets of this study include: 1) identification of a row house; 2) identification of sustainability criteria; 3) identification of the suitability of the row houses in each of the sustainability criteria. This research is a quantitative research. Data analysis technique is to use the scoring method. The results of this study are of 8 variables indicating that the row house is in accordance with the criteria of sustainability. The eight variables include: 1) physical empowerment of the environment that is beneficial to the environment; 2) pay attention to environmental impacts in carrying out development; 3) provision of basic infrastructure facilities for housing \& settlements; 4) community economic empowerment; 5) carrying capacity of economic, social, cultural institutions / institutions; 6) human resource development; 7) development does not damage the social integrity of the community; 8) maintaining cultural diversity. Except for the sub-variable impact on the environment shows that the housing series is less in accordance with sustainable criteria. Rating scoring all variables included in the appropriate category. The conclusion is that in general, a series of houses in the city of Surakarta are in accordance with the concept of sustainability, taking into account the location of development and its impact on the environment.
\end{abstract}

Keywords: row houses; suitability; sustainability criteria

\section{PENDAHULUAN}

Rumah deret adalah beberapa rumah yang satu atau lebih dari sisi bangunan menyatu dengan sisi satu atau lebih bangunan lain atau rumah lain, tetapi masing-masing mempunyai kavling sendiri (UU No. 1 tahun 2011). Rumah deret merupakan rumah yang saling menempel satu dengan yang lainnya. Kota Surakarta memiliki salah satu program yaitu pembangunan rumah deret. Tujuan pembangunan rumah deret di antaranya untuk penataan bantaran Kali Pepe sebagai wisata sungai, membangun rusunawa dengan konsep komprehensif mengintegrasikan aspek tempat tinggal, lahan usaha, 
penataan ruang publik dan infrastruktur lingkungan. Diharapkan dengan adanya rumah deret bisa memberikan manfaat sebagai lahan pengendali banjir dan meningkatkan kualitas lingkungan dengan memberdayakan ruang publik berbasis sungai. Konsep kampung deret ini dipertahankan karena dinilai memiliki potensi yang lebih dibandingkan dengan rusunawa biasa.

Sampai saat ini, rumah deret di Kota Surakarta yang telah dikerjakan di antaranya: tahun 2014 dibangun rumah deret I di Pringgading, Setabelan untuk 36 KK; tahun 2015 dibangun rumah deret II di Keprabon untuk 45 KK; tahun 2016 dibangun rumah deret III di Ketelan untuk 8 KK; dan tahun 2017 dibangun rumah deret IV Ketelan untuk 12 KK (tahap pembangunan). Peta persebaran lokasi rumah deret dapat dilihat pada Gambar 1. Dapat diketahui bahwa pembangunan rumah deret dilakukan setiap tahun oleh Pemerintah Kota Surakarta. Pembangunan tersebut dinilai memiliki potensi untuk mewujudkan hunian bagi masyarakat di permukiman kumuh, bahkan potensinya lebih besar dibandingkan dengan rumah susun. Rumah deret tersebut dibangun dengan memperhatikan berbagai aspek sosial, ekonomi, dan fisik. Berkaitan dengan pembangunan rumah deret tersebut, maka tujuan penelitian ini adalah untuk mengetahui kesesuaian rumah deret di Kota Surakarta terhadap kriteria keberlanjutan.

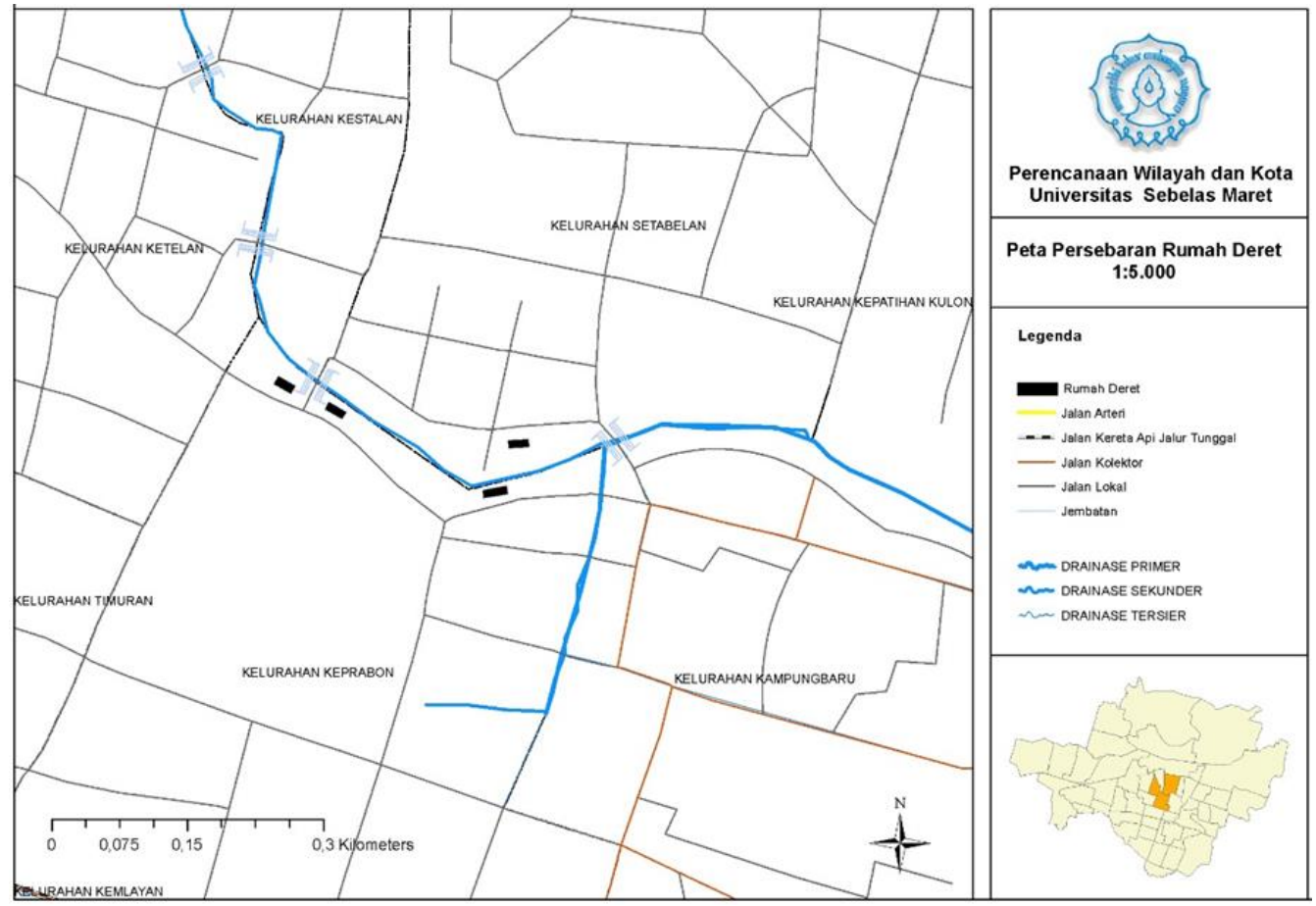

Gambar 1. Peta Persebaran Rumah Deret di Kota Surakarta

\section{KAJIAN PUSTAKA}

\subsection{RUMAH DERET}

Berdasarkan penjelasan pasal 22 ayat 2 Undang-Undang Nomor 1 tahun 2011 Tentang Perumahan dan Kawasan Permukiman, rumah deret adalah beberapa rumah yang satu atau lebih dari sisi bangunan menyatu dengan sisi satu atau lebih bangunan lain atau rumah lain, tetapi masing-masing mempunyai kavling sendiri. Sedangkan menurut Permen Negara Perumahan Rakyat Nomor 11 Tahun 2008, rumah deret adalah beberapa rumah tinggal lengkap, di mana satu atau lebih dari sisi bangunan induknya menyatu dengan sisi satu atau lebih bangunan rumah tinggal lainnya tetapi masing-masing mempunyai persil sendiri, ditujukan untuk memberikan peluang transisi antara perumahan unit tunggal dengan lingkungan perumahan yang berkepadatan tinggi. Dalam SNI 03-1733-2004 Tentang Tata Cara Perencanaan Lingkungan Perumahan di Perkotaan, rumah deret (hunian gandeng banyak) adalah beberapa tempat kediaman lengkap dimana satu atau lebih dari sisi bangunan induknya menyatu dengan sisi satu atau lebih bangunan lain atau tempat kediaman lain, tetapi masing-masing mempunyai persil sendiri. 
Zuraida (2013) mengemukakan bahwa rumah yang berdempetan/ berderet adalah rumah yang bersambung antara rumah yang satu dengan rumah lainnya. Jarak antara rumah yang satu dengan sampingnya tidak ada. Dinding rumah antara yang satu dengan lainnya berdempetan. Tidak ada lahan sisa atau kosong antara rumah yang satu dengan rumah sebelahnya. Rumah deret ini banyak ditemukan pada rumah-rumah yang dibangun oleh masyarakat di kampung dengan luasan yang minimal.

\subsection{PEMBANGUNAN BERKELANJUTAN}

Zulkifli (2009) menyebutkan bahwa kriteria dan indikator pembangunan berkelanjutan yang digunakan untuk menilai suatu usulan proyek dikategorikan menjadi 3 kelompok, yaitu keberlanjutan lingkungan, ekonomi, sosial dan teknologi. Tiga kriteria pertama adalah mengenai dampak lokal dari usulan proyek, sehingga batas wilayah evaluasi adalah lokal. Lebih spesifik lagi, lingkup evaluasi untuk kategori kriteria keberlanjutan lingkungan adalah wilayah yang mengalami dampak ekologis langsung akibat usulan proyek. Sementara lingkup evaluasi untuk kategori kriteria keberlanjutan ekonomi dan sosial adalah batas administratif kabupaten. Bila dampak ekonomi dan sosial dirasakan lintas kabupaten maka batas administrasi yang digunakan adalah semua kabupaten yang terkena dampak. Berbeda dengan ketiga kategori kriteria lainnya, batas evaluasi dari keberlanjutan teknologi adalah di tingkat nasional.

Berdasarkan Kleden (1992), pembangunan berkelanjutan didefinisikan sebagai sejenis pembangunan yang di satu pihak mengacu pemanfaatan sumber-sumber alam maupun sumber daya manusia secara optimal, dan di lain pihak serta pada saat yang sama memelihara keseimbangan optimal di antara berbagai tuntutan yang saling bertentangan terhadap sumber-sumber daya tersebut. Ada dua macam kelestarian atau ketahanan (sustainability) yang akan dibahas disini. Pertama adalah kelestarian fisik (physical sustainability), yang mengacu pada daya dukung sumber-sumber alam, seperti tanah, air dan hutan. Kedua adalah ketahanan sosial (social sustainability), yang mengacu pada daya dukung institusi sosial baik politik, ekonomi ataupun budaya. Kelestarian atau ketahanan fisik meliputi tiga sasaran utama. Pertama, pengelolaan hutan (termasuk pengelolaan sumber-sumber genetik), pemanfaatan dan pengelolaan tanah, serta pengelolaan pemasokan air. Kedua, analisis dampak lingkungan yang diperlukan bagi pengawasan atau kontrol pencemaran dan tingkat keracunan, maupun pengembangan dan pengelolaan lingkungan buatan. Ketiga, pengembangan sumber daya manusia yang terdiri dari kontrol terhadap pertumbuhan penduduk, perencanaan mobilitas penduduk, perbaikan kualitas hidup fisik maupun nonfisik. Di pihak lain, ketahanan sosial berurusan dengan tekanan demografis terhadap tanah atau sektor pertanian, persoalan mengenai sentralisasi atau desentralisasi pemerintahan, serta perlunya penataan institusional yang merupakan prasyarat bagi penciptaan kesempatan yang sama bagi semua orang. Berdasarkan Jaya (2004), konsep pembangunan berkelanjutan (sustainable development) di antaranya keberlanjutan ekologis, keberlanjutan ekonomi, keberlanjutan sosial budaya.

\subsection{PERMUKIMAN YANG BERKELANJUTAN}

Dalam Pedoman Pelaksanaan PNPM Mandiri Perkotaan (2012) diuraikan konsep dasar Tridaya dalam beberapa hal, di antaranya perlindungan lingkungan (environmental protection), pengembangan masyarakat (social development), pengembangan ekonomi (economic development). Menurut Suprijanto (2004) secara praksis, Konsep Tridaya yang sudah berkembang sebagai azas pelaksanaan pembangunan perumahan dan permukiman (prinsip pemberdayaan komponen sosial masyarakat, usaha dan ekonomi, serta lingkungan), tetap dapat ditumbuhkembangkan sebagai pendekatan pembangunan perumahan dan permukiman yang berkelanjutan di tingkat lokal. Pendekatan ini dilakukan dengan memadukan kegiatankegiatan penyiapan dan pemberdayaan masyarakat, serta kegiatan pemberdayaan kegiatan usaha ekonomi komunitas dengan kegiatan pendayagunaan prasarana dan sarana dasar perumahan dan permukiman sebagai satu kesatuan sistem yang tidak terpisahkan. Menurut Santoso (2013), inti dari pendekatan Tridaya, yaitu proses pemberdayaan masyarakat agar terbangun daya sosial sehingga tercipta masyarakat efektif, daya ekonomi sehingga tercipta masyarakat produktif, dan daya pembangunan sehingga tercipta masyarakat pembangunan yang peduli lingkungan dan prinsip-prinsip pembangunan berkelanjutan. 


\section{METODE PENELITIAN}

Penelitian ini merupakan penelitian kuantitatif. Teknik analisis data, yaitu dengan menggunakan metode skoring. Tahapan yang dilakukan adalah mengidentifikasi konsep rumah deret, mengidentifikasi kriteria keberkelanjutan, dan analisis kesesuaian rumah deret terhadap setiap kriteria keberlanjutan. Metode skoring dari setiap variabel dapat dilihat pada Tabel 1.

Tabel 1. Pembobotan Indikator

\begin{tabular}{|c|c|c|c|c|}
\hline No. & Variabel & Sub Variabel & Parameter & Indikator \\
\hline 1. & $\begin{array}{l}\text { Pemberdayaan fisik } \\
\text { lingkungan yang bermanfaat } \\
\text { bagi sekitar }\end{array}$ & - & $\begin{array}{l}\text { Persepsi warga rumah } \\
\text { deret terhadap beberapa } \\
\text { pernyataan dampak } \\
\text { pemberdayaan fisik } \\
\text { lingkungan }\end{array}$ & $\begin{array}{l}\text { Sesuai: jika skor } 548-708 \\
\text { Kurang Sesuai: jika skor } 329-548 \\
\text { Tidak Sesuai: jika skor } 235 \text { - } 329\end{array}$ \\
\hline 2. & $\begin{array}{l}\text { Memperhatikan dampak } \\
\text { lingkungan dalam } \\
\text { melaksanakan pembangunan }\end{array}$ & $\begin{array}{l}\text { Dampak terhadap } \\
\text { lingkungan } \\
\text { Dampak terhadap } \\
\text { masyarakat lokal }\end{array}$ & $\begin{array}{l}\text { Ada tidaknya parameter } \\
\text { dampak terhadap } \\
\text { lingkungan } \\
\text { Ada tidaknya parameter } \\
\text { dampak terhadap } \\
\text { masyarakat lokal }\end{array}$ & $\begin{array}{l}\text { Sesuai: jika skor } 6-9 \\
\text { Kurang Sesuai: jika skor } 3-6 \\
\text { Tidak Sesuai: jika skor } 0 \text { - } 3 \\
\text { Sesuai: jika skor } 6-9 \\
\text { Kurang Sesuai: jika skor } 3-6 \\
\text { Tidak Sesuai: jika skor } 0-3\end{array}$ \\
\hline 3. & $\begin{array}{l}\text { Penyediaan sarana dan } \\
\text { prasarana dasar perumahan } \\
\text { \& permukiman }\end{array}$ & $\begin{array}{l}\text { Sarana dan Prasarana } \\
\text { yang berkelanjutan }\end{array}$ & $\begin{array}{l}\text { Persepsi warga rumah } \\
\text { deret terhadap beberapa } \\
\text { pernyataan mengenai } \\
\text { sarana prasarana }\end{array}$ & $\begin{array}{l}\text { Sesuai: jika ada } 5 \text { - } 7 \text { sarana, } 5 \text { - } 8 \\
\text { prasarana } \\
\text { Kurang Sesuai: jika ada } 3 \text { - } 5 \text { sarana, } 3-5 \\
\text { prasarana } \\
\text { Tidak Sesuai: jika ada } 1 \text { - } 3 \text { sarana, } 1 \text { - } 3 \\
\text { prasarana } \\
\text { Sesuai: jika skor } 220 \text { - } 282 \\
\text { Kurang Sesuai: jika skor } 157-220 \\
\text { Tidak Sesuai: jika skor } 94 \text { - } 157\end{array}$ \\
\hline 4. & $\begin{array}{l}\text { Pemberdayaan ekonomi } \\
\text { masyarakat }\end{array}$ & - & $\begin{array}{l}\text { Persepsi warga rumah } \\
\text { deret terhadap beberapa } \\
\text { pernyataan mengenai } \\
\text { pemberdayaan ekonomi } \\
\text { masyarakat } \\
\end{array}$ & $\begin{array}{l}\text { Sesuai: jika skor } 767 \text { - } 987 \\
\text { Kurang Sesuai: jika skor } 548-767 \\
\text { Tidak Sesuai: jika skor } 329 \text { - } 548\end{array}$ \\
\hline 5. & $\begin{array}{l}\text { Daya dukung } \\
\text { institusi/lembaga ekonomi, } \\
\text { sosial }\end{array}$ & - & $\begin{array}{l}\text { Ada institusi dan } \\
\text { programnya yang } \\
\text { terlaksana di rumah deret }\end{array}$ & $\begin{array}{l}\text { Sesuai: terdapat lebih dari satu } \\
\text { institusi/lembaga dan programnya yang } \\
\text { mendukung } \\
\text { Kurang Sesuai: terdapat satu } \\
\text { institusi/lembaga dan programnya yang } \\
\text { mendukung } \\
\text { Tidak Sesuai: tidak terdapat } \\
\text { institusi/lembaga dan programnya yang } \\
\text { mendukung }\end{array}$ \\
\hline 6. & $\begin{array}{l}\text { Pembangunan sumber daya } \\
\text { manusia }\end{array}$ & - & $\begin{array}{l}\text { Persepsi warga rumah } \\
\text { deret terhadap beberapa } \\
\text { pernyataan mengenai } \\
\text { pembangunan SDM } \\
\end{array}$ & $\begin{array}{l}\text { Sesuai: jika skor } 329-423 \\
\text { Kurang Sesuai: jika skor } 235-329 \\
\text { Tidak Sesuai: jika skor } 141 \text { - } 235\end{array}$ \\
\hline 7. & $\begin{array}{l}\text { Pembangunan tidak merusak } \\
\text { integritas sosial masyarakat }\end{array}$ & - & $\begin{array}{l}\text { Ada tidaknya konflik di } \\
\text { rumah deret ketika } \\
\text { pembangunan }\end{array}$ & $\begin{array}{l}\text { Sesuai: jika skor } 6 \text { - } 9 \\
\text { Kurang Sesuai: jika skor } 3-6 \\
\text { Tidak Sesuai: jika skor } 1 \text { - } 3\end{array}$ \\
\hline 8. & $\begin{array}{l}\text { Mempertahankan } \\
\text { keanekaragaman budaya }\end{array}$ & - & $\begin{array}{l}\text { Persepsi warga rumah } \\
\text { deret terhadap beberapa } \\
\text { pernyataan konsep } \\
\text { kebudayaan di rumah deret }\end{array}$ & $\begin{array}{l}\text { Sesuai: jika skor } 220 \text { - } 282 \\
\text { Kurang Sesuai: jika skor } 157-220 \\
\text { Tidak Sesuai: jika skor } 94-157\end{array}$ \\
\hline
\end{tabular}




\section{HASIL DAN PEMBAHASAN}

\subsection{ASPEK PEMBERDAYAAN FISIK YANG BERMANFAAT BAGI LINGKUNGAN}

Aspek pemberdayaan fisik lingkungan yang bermanfaat bagi sekitar memiliki peran penting dalam kriteria keberlanjutan. Hasil kuesioner menunjukkan poin senilai 666 dalam rentang nilai 548-708, termasuk dalam kategori sesuai. Berdasarkan Pedoman Pendampingan Masyarakat Pelaksanaan Tridaya dalam Kamal (2005) dijelaskan kegiatan pemberdayaan fisik lingkungan, di antaranya dapat memberikan manfaat bagi lingkungan (keluarga maupun masyarakat), memecahkan permasalahan lingkungan perumahan dan permukiman, dan memberikan pengaruh pada lingkungan sosial dan ekonomi yang lebih baik.

Selain itu dalam Pedoman Pelaksanaan PNPM Mandiri Perkotaan (2012), pemberdayaan fisik lingkungan harus berorientasi pada perlindungan/pemeliharaan lingkungan. Menurut Santoso (2013), pemberdayaan fisik lingkungan dapat diharapkan bisa menciptakan masyarakat pembangunan yang peduli lingkungan dan prinsip-prinsip pembangunan berkelanjutan. Masyarakat rumah deret banyak yang berpendapat bahwa aspek pemberdayaan fisik yang ada telah bermanfaat bagi sekitar. Pemberdayaan fisik yang ada sifatnya kecil, seperti pembenahan saluran air (drainase, air kotor, air bersih). Sedangkan yang sifatnya besar adalah pembangunan rumah deret sendiri. Berdampak pada meningkatnya kualitas lingkungan yang dahulu kumuh dan kotor, sekarang menjadi rapi dan lebih tertata. Pengaruh tersebut juga memiliki dampak dalam hal sosial dan ekonomi.

\subsection{ASPEK MEMPERHATIKAN DAMPAK LINGKUNGAN DALAM MELAKSANAKAN PEMBANGUNAN}

\subsubsection{Dampak Terhadap Lingkungan}

Aspek dampak terhadap lingkungan merupakan salah satu aspek yang harus diperhatikan ketika melaksanakan pembangunan. Hasil penelitian menunjukkan poin senilai 5 dalam rentang nilai 3-6, termasuk dalam kategori kurang sesuai. Menurut Emil (1993) kebijakan pengelolaan dampak pembangunan terhadap lingkungan di antaranya: penerapan analisis dampak pembangunan terhadap lingkungan; pengendalian pencemaran, khususnya bahan berbahaya dan beracun; serta pengelolaan lingkungan binaan manusia, man made environment, seperti kota, waduk dan lain sebagainya. Pembangunan rumah deret di Kota Surakarta juga memperhatikan dampak terhadap lingkungan. Proses Analisis Mengenai Dampak Lingkungan (AMDAL) telah dilaksanakan sebelum pembangunan. Akan tetapi, untuk pengendalian pencemaran ketika rumah deret dibangun belum dilakukan secara maksimal, misalnya pencemaran suara yang berakibat pada kebisingan. Pengelolaan lingkungan binaan juga belum dilaksanakan secara maksimal, misalnya belum adanya lingkungan buatan manusia, yaitu taman yang dikelola.

\subsubsection{Dampak Terhadap Masyarakat Lokal}

Aspek dampak terhadap masyarakat lokal merupakan salah satu aspek yang harus diperhatikan ketika melaksanakan pembangunan. Hasil penelitian menunjukkan poin senilai 9 dalam rentang nilai 6-9, termasuk dalam kategori sesuai. Berdasarkan Zulkifli (2009), kriteria keselamatan dan kesehatan masyarakat lokal terdiri dari beberapa indikator di antaranya: tidak menyebabkan timbulnya gangguan kesehatan, dipatuhinya peraturan keselamatan kerja, adanya prosedur yang terdokumentasi yang menjelaskan usaha-usaha yang memadai untuk mencegah kecelakaan dan mengatasi bila terjadi kecelakaan.

Masyarakat di rumah deret berpendapat bahwa pembangunan rumah deret tidak berdampak buruk terhadap fisik, khususnya kesehatan. Aspek keselamatan kerja dan upaya dalam menghadapi kecelakaan telah dilakukan sehingga tidak terjadi kecelakaan kerja ketika pembangunan rumah deret. 


\subsection{ASPEK PENYEDIAAN SARANA DAN PRASARANA DASAR PERUMAHAN DAN PERMUKIMAN}

\subsubsection{Ketersediaan Sarana dan Prasarana Dasar}

Aspek ketersediaan sarana dan prasarana dasar merupakan salah satu aspek yang harus diperhatikan ketika menyediakan sarana prasarana dasar perumahan dan permukiman. Hasil kuesioner menunjukkan poin senilai 9 dalam rentang nilai 6-9, termasuk dalam kategori sesuai. Sarana dan prasarana dasar perumahan dan permukiman untuk rumah deret di antaranya sebagai berikut (lihat Tabel 2).

Tabel 2. Sarana \& Prasarana Dasar Perumahan dan Permukiman

\begin{tabular}{|c|c|}
\hline Sarana & Prasarana \\
\hline $\begin{array}{ll}\text { - } & \text { Sarana pemerintahan dan pelayanan umum } \\
\text { - } & \text { Sarana pendidikan dan pembelajaran } \\
\text { - } & \text { Sarana kesehatan } \\
\text { - } & \text { Sarana peribadatan } \\
\text { - } & \text { Sarana perdagangan dan niaga } \\
\text { - } & \text { Sarana kebudayaan dan rekreasi } \\
\text { - } & \text { Sarana ruang terbuka, taman dan lapangan olahraga }\end{array}$ & $\begin{array}{ll}\text { - } & \text { Prasarana/utilitas - jaringan jalan } \\
\text { - } & \text { Prasarana/utilitas - jaringan drainase } \\
\text { - } & \text { Prasarana/utilitas - jaringan air bersih } \\
\text { - } & \text { Prasarana/utilitas - jaringan air limbah } \\
\text { - } & \text { Prasarana/utilitas - jaringan persampahan } \\
\text { - } & \text { Prasarana/utilitas - jaringan listrik } \\
\text { - } & \text { Prasarana/utilitas - jaringan telepon } \\
\text { - } & \text { Prasarana/utilitas - jaringan transportasi lokal }\end{array}$ \\
\hline
\end{tabular}

Sumber: SNI 03-7033-2004, Tata Cara Perencanaan Lingkungan Perumahan di Perkotaan

Dari penjelasan di atas, jumlah sarana minimal ada 7 dan jumlah prasarana minimal ada 8. Setiap sarana \&danprasarana telah ada di rumah deret. Sarana pemerintahan dan pelayanan umum, yaitu balai pertemuan, tempat parkir, pos ronda, kantor kelurahan. Sarana pendidikan dan pembelajaran, yaitu pojok baca, SD, SMP, SMA. Sarana kesehatan, yaitu puskesmas. Sarana peribadatan, yaitu masjid. Sarana perdagangan dan niaga, yaitu warung, toko, kios. Sarana kebudayaan dan rekreasi, yaitu balai warga. Sarana ruang terbuka, taman dan lapangan olahraga, yaitu taman bermain, taman PKK.

Prasarana yang telah ada dan terpenuhi di rumah deret, yaitu jaringan jalan, drainase, air bersih, air limbah, persampahan, listrik, telepon dan trasnportasi lokal. Untuk transportasi lokal harus dijangkau dengan jalan kaki sekitar 50 meter ke halte. Secara umum sarana dan prasarana telah terpenuhi dan masih layak pakai.

\subsubsection{Sarana dan Prasarana Berkelanjutan}

Aspek sarana dan prasarana yang berkelanjutan merupakan salah satu aspek yang harus diperhatikan ketika sarana prasarana dasar perumahan dan permukiman telah tersedia. Hasil kuesioner menunjukkan poin senilai 277 dalam rentang nilai 220-282, termasuk dalam kategori sesuai. Menurut Pedoman Pelaksanaan PNPM Mandiri Perkotaan (2012), persyaratan sarana dan prasarana berkelanjutan adalah sarana dan prasarana yang kondusif dalam membangun solidaritas sosial dan meningkatkan kesejahteraan penduduknya. Menurut Suprijanto (2004), persyaratan sarana dan prasarana berkelanjutan adalah mendayagunakan sarana prasarana untuk aspek sosial dan ekonomi yang ada. Masyarakat rumah deret berpendapat bahwa sarana dan prasarana yang tersedia telah sesuai dengan kriteria berkelanjutan, yaitu sarana dan prasarana yang tersedia memiliki andil dalam membangun solidaritas sosial, sarana dan prasarana yang tersedia memiliki andil dalam aspek sosial dan ekonomi masyarakat rumah deret.

\subsection{ASPEK PEMBERDAYAAN EKONOMI MASYARAKAT}

Aspek pemberdayaan ekonomi masyarakat menghasilkan kuesioner senilai 771 dalam rentang nilai 767-987, termasuk dalam kategori sesuai. Berdasarkan Pedoman Pendampingan Masyarakat Pelaksanaan Tridaya dalam Kamal (2005) kegiatan pemberdayaan ekonomi/usaha di antaranya:

- Kegiatan dapat memberikan dampak secara ekonomi bagi individu, masyarakat, keluarga maupun masyarakat secara luas

- Kegiatan yang dilakukan dapat berfungsi sebagai income generating

- Kegiatan yang dilakukan dapat menjadi embrio bagi penciptaan lapangan kerja baru

Menurut Suprijanto (2004) secara praksis, konsep Tri Daya yang sudah berkembang sebagai azas pelaksanaan pembangunan perumahan dan permukiman (prinsip pemberdayaan komponen sosial masyarakat, usaha dan ekonomi, serta 
lingkungan), tetap dapat ditumbuhkembangkan sebagai pendekatan pembangunan perumahan dan permukiman yang berkelanjutan di tingkat lokal. Pendekatan ini dilakukan dengan memadukan kegiatan-kegiatan penyiapan dan pemberdayaan masyarakat, serta kegiatan pemberdayaan kegiatan usaha ekonomi komunitas dengan kegiatan pendayagunaan prasarana dan sarana dasar perumahan dan permukiman sebagai satu kesatuan sistem yang tidak terpisahkan. Menurut Santoso (2013) inti dari pendekatan Tridaya, yaitu proses pemberdayaan masyarakat agar terbangun daya sosial sehingga tercipta masyarakat efektif, daya ekonomi sehingga tercipta masyarakat produktif, dan daya pembangunan sehingga tercipta masyarakat pembangunan yang peduli lingkungan dan prinsip-prinsip pembangunan berkelanjutan.

Dari empat sumber di atas maka parameter pemberdayaan ekonomi masyarakat memuat kegiatan sebagai berikut:

- Kesejahteraan masyarakat lokal yang berkesinambungan

- Pemerataan kesejahteraan masyarakat

- Dapat memberikan dampak secara ekonomi bagi individu, masyarakat, keluarga maupun masyarakat secara luas

- Dapat berfungsi sebagai income generating

- Dapat menjadi embrio bagi penciptaan lapangan kerja baru

- Meningkatkan kapasitas dan keterampilan masyarakat miskin dan/atau pengangguran

- Mengembangkan peluang usaha dan akses ke sumber daya kunci guna peningkatan pendapatan dengan tetap memperhatikan dampak lingkungan fisik dan sosial.

- Memberdayakan kegiatan usaha ekonomi komunitas

Secara umum, masyarakat rumah deret telah merasakan dampak dari adanya kegiatan pemberdayaan ekonomi masyarakat. Dampak yang telah terasa, yaitu pendapatan masyarakat menjadi naik, berkesinambungan, merata, meningkatnya keterampilan. Akan tetapi, terdapat permasalahan, yaitu pemberdayaan ekonomi belum berdaya sepenuhnya dan belum bisa memunculkan lapangan kerja yang baru karena pemberdayaan hanya sebatas bantuan pasif. Pemerintah melakukan pemberian kepada masyarakat dan masyarakat hanya menerima kemudian habis begitu saja.

\subsection{ASPEK DAYA DUKUNG INSTITUSI LEMBAGA SOSIAL/EKONOMI}

Berdasarkan Kleden (1992), ada dua macam kelestarian atau ketahanan (sustainability) yang akan dibahas disini. Pertama adalah kelestarian fisik (physical sustainability) yang mengacu pada daya dukung sumber-sumber alam, seperti tanah, air dan hutan. Kedua adalah ketahanan sosial (social sustainability) yang mengacu pada daya dukung institusi sosial baik politik, ekonomi ataupun budaya. Pada aspek ini difokuskan untuk daya dukung institusi, sosial, ekonomi, dll. Institusi/lembaga yang telah memiliki peran untuk rumah deret di antaranya sebagai berikut (lihat Tabel 3).

Tabel 3. Kontribusi/Program dari Institusi/Lembaga terhadap Rumah Deret

\begin{tabular}{|c|c|c|}
\hline No. & Nama Rumah Deret & Lembaga \& Program \\
\hline 1. & Pringgading, Setabelan & $\begin{array}{ll}\text { - } & \text { Pemerintah Kota Surakarta membantu material bangunan } \\
\text { - } & \text { PMS (Perkumpulan Masyarakat Surakarta) membantu uang kemudian dibelikan } \\
& \text { material bangunan } \\
\text { - } & \text { BLUD (Badan Layanan Umum Daerah) mendesain bangunan rumah deret } \\
\text { - } & \text { CV Ulin, Pringgading, kontraktor swasta yang membangun rumah deret } \\
\text { - } & \text { Bank BTN Syariah yang memberikan dana untuk pembangunan rumah deret kepada } \\
& \text { CV Ulin langsung } \\
\text { - } & \text { Warung murah dari Dinas Sosial }\end{array}$ \\
\hline 2. & Keprabon & $\begin{array}{l}\text { - DPU Kota Surakarta yang membantu proses pembangunan dari awal sampai akhir } \\
\text { - } \quad \text { Arkom Jogja membantu proses sosialisasi pembangunan rumah deret } \\
\text { - } \quad \text { PNPM, Kotaku, KUR berupa pinjaman lunak dengan bunga ringan untuk modal usaha }\end{array}$ \\
\hline 3. & Ketelan & $\begin{array}{l}\text { - DPU Kota Surakarta yang membantu proses pembangunan dari awal sampai akhir } \\
\text { - } \quad \text { Arkom Jogja membantu proses sosialisasi pembangunan rumah deret } \\
\text { - Warung Murah dari Dinas Sosial }\end{array}$ \\
\hline
\end{tabular}

Secara umum telah terdapat lembaga dan programnya yang telah berjalan di rumah deret. Lembaga dan program tersebut berupa bantuan pembangunan, bantuan untuk keperluan rumah tangga (sembako), bantuan kredit, dll. Bantuan pembangunan 
dan rumah tangga (sembako) telah berjalan dengan lancar. Bantuan kredit telah berjalan, akan tetapi belum memiliki dampak yang signifikan terhadap kelangsungan usaha masyarakat rumah deret.

\subsection{ASPEK PEMBANGUNAN SUMBER DAYA MANUSIA}

Pembangunan sumber daya manusia meliputi: 1) adanya upaya pengembangan masyarakat, maka memberikan dorongan percaya diri untuk dapat berkembang dan masyarakat mempunyai arti penting dalam pembangunan yang akan dan sedang dilakukan; 2) upaya pengembangan masyarakat dikembangkan secara sosial dan ekonomi; 3) adanya upaya pengembangan masyarakat, maka masyarakat berpartisipasi di dalamnya. Upaya-upaya pembangunan sumber daya manusia di rumah deret telah terselenggara, dari mulai formal hingga non formal. Akan tetapi, belum terdapat institusi pengembangan yang bertumpu pada komunitas. Beberapa pembangunan SDM di rumah deret di antaranya sebagai berikut (lihat Tabel 4).

Tabel 4. Macam Pembangunan SDM

\begin{tabular}{|c|c|c|c|c|}
\hline No & Macam Pembangunan SDM & $\begin{array}{l}\text { Pringgading, } \\
\text { Setabelan }\end{array}$ & Keprabon & Ketelan \\
\hline 1. & $\begin{array}{l}\text { Proses konsultasi dari pemerintah ke } \\
\text { masyarakat lokal }\end{array}$ & Ada & Ada & $\begin{array}{l}\text { Ada } \\
\text { Dibangun selama } 9 \\
\text { bulan }\end{array}$ \\
\hline 2. & $\begin{array}{l}\text { Ada tanggapan dan tindak lanjut } \\
\text { terhadap komentar, keluhan } \\
\text { masyarakat lokal }\end{array}$ & Ada & Ada & Ada \\
\hline 3. & Kontrol terhadap kependudukan & $\begin{array}{l}\text { - Periksa jentik-jentik } \\
\text { - Posyandu balita } \\
\text { - Posyandu lansia } \\
\text { - Puskesmas keliling }\end{array}$ & $\begin{array}{l}\text { Ada } \\
\text { Yang tertera di KK } \\
\text { bisa menempati } \\
\text { - Periksa jentik-jentik } \\
\text { - Posyandu balita } \\
\text { - Posyandu lansia } \\
\text { - Puskesmas keliling }\end{array}$ & $\begin{array}{l}\text { Jentik-jentik nyamuk } \\
\text { Cek gula darah, } \\
\text { asam urat } \\
\text { Cek up medis } 40 \\
\text { tahun ke atas } \\
\text { di LPMK }\end{array}$ \\
\hline 4. & $\begin{array}{l}\text { Upaya pengembangan masyarakat di } \\
\text { rumah deret }\end{array}$ & $\begin{array}{l}\text { - Les anak-anak SD } \\
\text { hari Senin \& Jumat, } \\
\text { habis isya' } \\
\text { - Dari kelurahan } 1 \\
\text { tahun sekali atau 0,5 } \\
\text { tahun sekali } \\
\text { - PKK }\end{array}$ & $\begin{array}{l}\text { - Les anak-anak, } \\
\text { dengan pengasuh } \\
\text { karang taruna, } \\
\text { mahasiswa UNS } \\
\text { (30-an siswa) } \\
\text { - SD (Senin, Selasa, } \\
\text { Rabu) } \\
\text { - SMP (Kamis, } \\
\text { Jumat, Sabtu) } \\
\text { - Kursus (dari } \\
\text { Kelurahan) } \\
\text { menjahit, rias } \\
\text { manten }\end{array}$ & Tidak ada \\
\hline 5. & $\begin{array}{l}\text { Community-Based Institusional } \\
\text { Development (Institusi } \\
\text { Pengembangan Bertumpu Pada } \\
\text { Kelompok/Komunitas) }\end{array}$ & Tidak ada & Tidak ada & Tidak ada \\
\hline
\end{tabular}

\subsection{ASPEK PEMBANGUNAN TIDAK MERUSAK INTEGRITAS SOSIAL}

Menurut Zulkifli (2009), proyek/pembangunan agar tidak merusak integritas sosial masyarakat memiliki indikator, yaitu tidak menyebabkan konflik di tengah masyarakat lokal. Berdasarkan wawancara dengan perwakilan masyarakat rumah deret, pembangunan Rumah Deret Setabelan tidak ada konflik. Pembangunan Rumah Deret Ketelan tidak ada konflik. Pembangunan Rumah Deret Keprabon terdapat konflik ringan berupa adu mulut. Secara umum, masyarakat rumah deret memiliki integritas sosial masyarakat karena pembangunan rumah deret tidak terjadi konflik kecuali di Rumah Deret Keprabon, 
itupun konflik ringan. Hal tersebut dipengaruhi dengan kegigihan sosialisasi dari pihak pemerintah dan swasta terhadap masyarakat rumah deret.

\subsection{ASPEK MEMPERTAHANKAN KEANEKARAGAMAN BUDAYA}

Jaya (2004) menyebutkan bahwa mempertahankan keanekaragaman budaya dengan mengakui dan menghargai sistem sosial \& kebudayaan seluruh bangsa dengan memahami serta menggunakan pengetahuan tradisional demi manfaat masyarakat \& pembangunan ekonomi. Mempertahankan keanekaragaman budaya merupakan salah satu poin yang ada dalam aspek berkelanjutan. Kebudayaan yang ada di masyarakat, misalnya upacara adat, kenduri, upacara pengantin, selametan, kegiatan keagamaan, dll. Pada Rumah Deret Keprabon terdapat kebudayaan, di antaranya pengajian bagi pemeluk agama islam, ibadah bagi pemeluk agama kristen setiap Hari Kamis. Kemudian di Rumah Deret Ketelan, tidak ada kebudayaan karena penghuninya sedikit. Di Rumah Deret Setabelan ada kebudayaan, di antaranya kenduri dan upacara pengantin. Secara umum masyarakat masih mengakui dan menggunakan sistem sosial atau kebudayaan di rumah deret. Komunitas masyarakat mempengaruhi terbentuknya sistem sosial atau kebudayaan. Sistem sosial atau kebudayaan yang ada belum sampai pada tahap memberikan pembangunan ekonomi.

Berikut ini merupakan resume analisis dan pembahasan dari masing-masing variabel yang ada di atas (lihat Tabel 5).

Tabel 5. Resume Hasil Analisis dan Pembahasan

\begin{tabular}{llll}
\hline No. & \multicolumn{1}{c}{ Variabel } & Hasil & \multicolumn{1}{c}{ Pembahasan } \\
\hline 1. & Pemberdayaan Fisik & Sesuai & Masyarakat rumah deret banyak yang berpendapat bahwa aspek \\
& Lingkungan yang Bermanfaat & & pemberdayaan fisik yang ada telah bermanfaat bagi sekitar. Pemberdayaan \\
& Bagi Sekitar & fisik yang ada sifatnya kecil, seperti pembenahan saluran air (drainase, air \\
& & kotor, air bersih). Sedangkan, yang sifatnya besar adalah pembangunan rumah \\
& & deret sendiri. Berdampak pada meningkatnya kualitas lingkungan, yang dahulu \\
& & kumuh \& kotor, sekarang menjadi rapi \& lebih tertata. Pengaruh tersebut juga \\
& & memiliki dampak dalam hal sosial \& ekonomi. \\
\hline
\end{tabular}

2. Memperhatikan Dampak

Lingkungan dalam

Melaksanakan Pembangunan

$\begin{array}{ll}\text { A. Dampak Terhadap } & \text { Kurang } \\ \text { Lingkungan } & \text { Sesuai }\end{array}$

Pembangunan rumah deret di Kota Surakarta juga memperhatikan dampak terhadap lingkungan. Proses Analisis Mengenai Dampak Lingkungan (AMDAL) telah dilaksanakan sebelum pembangunan. Akan tetapi, untuk pengendalian pencemaran ketika rumah deret dibangun belum dilakukan secara maksimal. Pengelolaan lingkungan binaan juga belum dilaksanakan secara maksimal.

B. Dampak Terhadap Sesual Masyarakat di rumah deret berpendapat bahwa pembangunan rumah deret Masyarakat Lokal tidak berdampak buruk terhadap fisik, khususnya kesehatan. Aspek keselamatan kerja dan upaya dalam menghadapi kecelakaan telah dilakukan. Tidak terjadi kecelakaan kerja ketika pembangunan rumah deret.

3. Penyediaan Sarana

Prasarana Dasar Perumahan

\& Permukiman

A. Ketersediaan Sarana dan Sesuai Prasarana Dasar

Setiap sarana dan prasarana telah ada di rumah deret. Sarana pemerintahan \& pelayanan umum, yaitu balai pertemuan, tempat parkir, pos ronda, kantor kelurahan. Sarana pendidikan \& pembelajaran, yaitu pojok baca, SD, SMP, SMA. Sarana kesehatan, yaitu puskesmas. Sarana peribadatan, yaitu masjid. Sarana perdagangan \& niaga, yaitu warung, toko, kios. Sarana kebudayaan \& rekreasi, yaitu balai warga. Sarana ruang terbuka, taman \& lapangan olahraga, yaitu taman bermain, taman PKK.

Prasarana yang telah ada \& terpenuhi di rumah deret, yaitu jaringan jalan, drainase, air bersih, air limbah, persampahan, listrik, telepon \& trasnportasi lokal. Untuk transportasi lokal harus dijangkau dengan jalan kaki sekitar 50 meter ke halte. Secara umum sarana dan prasarana telah terpenuhi \& masih layak pakai. 


\begin{tabular}{|c|c|c|c|}
\hline No. & Variabel & Hasil & Pembahasan \\
\hline & $\begin{array}{l}\text { B. Sarana dan Prasarana } \\
\text { yang Berkelanjutan }\end{array}$ & Sesuai & $\begin{array}{l}\text { Masyarakat rumah deret berpendapat bahwa sarana dan prasarana yang } \\
\text { tersedia telah sesuai dengan kriteria berkelanjutan, yaitu sarana dan prasarana } \\
\text { yang tersedia memiliki andil dalam membangun solidaritas sosial, sarana dan } \\
\text { prasarana yang tersedia memiliki andil dalam aspek sosial \& ekonomi } \\
\text { masyarakat rumah deret. }\end{array}$ \\
\hline 4. & $\begin{array}{l}\text { Pemberdayaan Ekonomi } \\
\text { Masyarakat }\end{array}$ & Sesuai & $\begin{array}{l}\text { Secara umum, masyarakat rumah deret telah merasakan dampak dari adanya } \\
\text { kegiatan pemberdayaan ekonomi masyarakat. Dampak yang telah terasa, yaitu } \\
\text { pendapatan masyarakat menjadi naik, berkesinambungan, merata, } \\
\text { meningkatnya keterampilan. Akan tetapi, terdapat permasalahan, yaitu } \\
\text { pemberdayaan ekonomi belum berdaya sepenuhnya dan belum bisa } \\
\text { memunculkan lapangan kerja yang baru karena pemberdayaan hanya sebatas } \\
\text { bantuan pasif. Pemerintah melakukan pemberian kepada masyarakat dan } \\
\text { masyarakat hanya menerima kemudian habis begitu saja }\end{array}$ \\
\hline 5. & $\begin{array}{l}\text { Daya Dukung } \\
\text { Institusi/Lembaga }\end{array}$ & Sesuai & $\begin{array}{l}\text { Secara umum telah terdapat lembaga dan programnya yang telah berjalan di } \\
\text { rumah deret. Lembaga dan program tersebut, berupa bantuan pembangunan, } \\
\text { bantuan untuk keperluan rumah tangga (sembako), bantuan kredit, dll. Bantuan } \\
\text { pembangunan \& rumah tangga (sembako) telah berjalan dengan lancar. } \\
\text { Bantuan kredit telah berjalan, akan tetapi belum memiliki dampak yang } \\
\text { signifikan terhadap kelangsungan usaha masyarakat rumah deret. }\end{array}$ \\
\hline 6. & $\begin{array}{l}\text { Pembangunan Sumber Daya } \\
\text { Manusia }\end{array}$ & Sesuai & $\begin{array}{l}\text { Upaya-upaya pembangunan sumber daya manusia di rumah deret telah } \\
\text { terselenggara, dari mulai formal hingga non formal. Akan tetapi belum terdapat } \\
\text { institusi pengembangan yang bertumpu pada komunitas. }\end{array}$ \\
\hline 7. & $\begin{array}{l}\text { Pembangunan Tidak Merusak } \\
\text { Integritas Sosial Masyarakat }\end{array}$ & Sesuai & $\begin{array}{l}\text { Secara umum, masyarakat rumah deret memiliki integritas sosial masyarakat } \\
\text { karena pembangunan rumah deret tidak terjadi konflik kecuali di Rumah Deret } \\
\text { Keprabon, itupun konflik ringan. Hal tersebut dipengaruhi dengan kegigihan } \\
\text { sosialisasi dari pihak pemerintah \& swasta terhadap masyarakat rumah deret. }\end{array}$ \\
\hline 8. & $\begin{array}{l}\text { Mempertahankan } \\
\text { Keanekaragaman Budaya }\end{array}$ & Sesuai & $\begin{array}{l}\text { Secara umum masyarakat masih mengakui dan menggunakan sistem sosial } \\
\text { atau kebudayaan di rumah deret. Komunitas masyarakat mempengaruhi } \\
\text { terbentuknya sistem sosial atau kebudayaan. Sistem sosial atau kebudayaan } \\
\text { yang ada belum sampai pada tahap memberikan pembangunan ekonomi. }\end{array}$ \\
\hline
\end{tabular}

\section{KESIMPULAN}

Hasil penelitian dari 8 variabel menunjukkan bahwa 7 variabel rumah deret telah sesuai dengan kriteria berkelanjutan. Tujuh variabel tersebut, yaitu: 1) pemberdayaan fisik lingkungan yang bermanfaat bagi sekitar; 2) penyediaan sarana dan prasarana dasar perumahan \& permukiman; 3) pemberdayaan ekonomi masyarakat; 4) daya dukung institusi/lembaga ekonomi, sosial, budaya; 5) pembangunan sumber daya manusia; 6) pembangunan tidak merusak integritas sosial masyarakat; 7) mempertahankan keanekaragaman budaya. Kecuali pada variabel memperhatikan dampak lingkungan dalam melaksanakan pembangunan, sub variabel dampak terhadap lingkungan menunjukkan bahwa rumah deret kurang sesuai dengan kriteria berkelanjutan. Kesimpulannya adalah secara umum, rumah deret di Kota Surakarta telah sesuai dengan konsep berkelanjutan dengan memperhatikan lokasi pembangunan dan dampaknya terhadap lingkungan.

\section{DAFTAR PUSTAKA}

Emil, S. (1993). Pembangunan Berwawasan Lingkungan. Jakarta: Penerbit LP3ES, Cet. ke-6.

Jaya, A. (2004). Konsep Pembangunan Berkelanjutan (Sustainable Development). Tugas Individu Program S3 Institut Pertanian Bogor, 111. Diakses dari

ACE_SURYADI/askar_jaya.pdf

Kamal, M. (2005). Manfaat Penataan Permukiman Kumuh Terhadap Masyarakat Nelayan di Kawasan Bandengan Kabupaten Kendal. Tesis. Magister Teknik Pembangunan Wilayah dan Kota Universitas Diponegoro, Semarang. Diakses dari http://eprints.undip.ac.id/12882/1/2005MTPWK4233.pdf 
Desa-Kota, Vol. 3, No. 1, 2021, 92-102

Kementerian Pekerjaan Umum Direktorat Jenderal Cipta Karya. (2012). Pedoman Pelaksanaan PNPM Mandiri Perkotaan. Diakses dari https://docplayer.info/31483006-Pedoman-pelaksanaan-pnpm-mandiri-perkotaan-program-nasional-pemberdayaan-masyarakatpnpm-mandiri-perkotaan.html

Kleden, I. (1992). Pendahuluan ke Arah Pembangunan Berkelanjutan di Indonesia, in Yayasan SPES (Ed.) Buku Pembangunan Berkelanjutan, Mencari Format Politik. Jakarta: PT Gramedia Pustaka Utama.

Peraturan Menteri Negara Perumahan Rakyat Nomor 11 Tahun 2008 tentang Pedoman Keserasian Kawasan Perumahan dan Permukiman. Diakses dari https://peraturan.go.id/peraturan/view.html?id=11e44c512c9af640adfa313233333435

Santoso, S. (2013). Dukungan Swadaya Masyarakat dalam Program P2KP Atau PNPM Mandiri Perkotaan. Ekuilibrium Jurnal IImiah Bidang IImu Ekonomi, 8(2), 1-12. DOI: 10.24269/ekuilibrium.v8i2.39

SNI 03-1733-2004 tentang Tata Cara Perencanaan Lingkungan Perumahan di Perkotaan. Diakses dari http://sni.litbang.pu.go.id/index.php?r=/sni/new/sni/detail/id/694

Suprijanto, I. (2004). Reformasi Kebijakan \& Strategi Penyelenggaraan Perumahan \& Permukiman. Dimensi Journal of Architecture and Built Environment, 32(2). DOI: doi.org/10.9744/dimensi.32.2.

Undang-Undang Nomor 1 Tahun 2011 tentang Perumahan dan Kawasan Permukiman. Diakses dari https://jdihn.go.id/files/4/2011uu001.pdf

Zulkifli, A. (2009). Prinsip Pengelolaan Pembangunan Berkelanjutan atau The Principles of Sustainability Development. Diakses dari https://bangazul.com/prinsip-pembangunan-berkelanjutan-2/.

Zuraida, \& Latiefa, U. (2013). Pengaruh Pola Penataan Ruang Rumah Deret Terhadap Pengoptimalan Angin. Simposium Nasional Teknologi Terapan, A13-A17. Diakses dari https://publikasiilmiah.ums.ac.id/bitstream/handle/11617/4145/TA_003_Zuraida.pdf?sequence=1\&isAllowed=y 